\title{
INSENTIF EKONOMI TERHADAP USAHA AQUACULTURE
}

\author{
Mira \\ Balai Besar Riset Sosial Ekonomi, Kementrian Kelautan dan Perikanan \\ Jalan KS Tubun Petamburan VI Jakarta 10260 Telepon 021-53650162 \\ E -mail: miraclenia@yahoo.com
}

Diterima 8 November 2011 / Disetujui 1 Juli 2012

\begin{abstract}
The purpose of this study is to analyze the incentives for aquaculture businesses, one of these efforts is seaweed in Bone, South Sulawesi. Government intervention to develop the aquaculture business can be seen from the incentives provided. Incentives can be subsidized (at nursery) or in the form of protection (when the product is sold in the market). Incentives provided by the government in the form of policies, pay tax breaks or subsidies, have not touched this aquaculture business effectively. It can be seen from the value of the effectiveness of incentives for a commodity that is less than one (0.67). The government has not provided direct subsidies to farmers, unlike the fishing effort to get direct subsidies in the form of fuel prices (fuel oil) are relatively inexpensive for the fishermen. It can be seen from the value of subsidies for farmers who are negative (-0.3).
\end{abstract}

Keywords: incentives, aquaculture, farmers direct subsidies

\begin{abstract}
Abstrak: Tujuan dari penelitian ini menganalisis insentif terhadap usaha aquaculture, salah satunya adalah rumput laut di Bone, Sulawesi Selatan. Intervensi pemerintah untuk mengembangkan usaha aquaculture bisa dilihat dari insentif yang diberikannya. Insentif bisa berupa subsidi (saat pembibitan) atau berupa proteksi (saat produk tersebut dijual di pasar). Insentif yang diberikan pemerintah berupa kebijakan, keringanan pajak, atau subsidi, belum menyentuh secara efektif usaha aquaculture ini. Hal itu bisa dilihat dari nilai dari keefektifan insentif terhadap suatu komoditas yang kurang dari satu $(0,67)$. Pemerintah belum memberikan subsidi langsung ke pembudidaya, tidak seperti usaha penangkapan yang mendapatkan subsidi langsung berupa harga BBM (bahan bakar minyak) yang relatif murah untuk nelayan. Hal ini bisa dilihat dari nilai subsidi untuk pembudidaya yang bertanda negatif $(-0,3)$.
\end{abstract}

Kata kunci: insentif, aquaculture, petani, subsidi langsung

\section{PENDAHULUAN}

Dalam rangka mengurangi tingkat pengangguran dan kemiskinan, Kabinet Indonesia Bersatu melakukan program revitalisasi pertanian, perikanan, dan kehutanan. Pada tahap awal, program yang dicanangkan presiden tanggal 11 Juni 2005 di Purwakarta ini memfokuskan pada tiga komoditi andalan, salah satunya adalah rumput laut. Potensi lahan untuk budidaya rumput laut di Indonesia sebesar 1.110 .900 ha, namun, baru 20 persen (222.180 ha) yang efektif dimanfaatkan untuk budidaya rumput laut.
Indonesia adalah pemasok 15 persen rumput laut di pasar dunia dengan total 250 ribu ton rumput laut per tahun, nomor dua setelah Filipina yang memasok 80 persen kebutuhan pasar dunia, sedangkan lima persen lagi dihasilkan sejumlah negara lainnya. Jusuf (2006) mengelompokkan potensi pasar rumput laut ke dalam pasar domestik (lokal dan rumah tangga), dan pasar ekspor. Permintaan negara lain terhadap rumput laut Indonesia berasal dari berbagai negara. Negara tujuan ekspor rumput laut Indonesia adalah Cina, Hongkong, Filipina, Korea, Denmark, Spanyol, Perancis, dan USA. Di antara berbagai negara itu, pasar Asia lah 
yang menjadi negara tujuan ekspor rumput laut dari Indonesia.

Guna memacu produksi sebesar 10 juta ton rumput laut hingga 2014, Kementerian Kelautan dan Perikanan (KKP) tengah menyiapkan 60 klaster lahan untuk pengembangan usaha rumput laut. Saat ini, beberapa pemerintah Daerah (Pemda) bersama swasta baru membangun klaster rumput laut di (Jawa Timur, Gorontalo, Sulawesi Selatan, Nusa Tenggara Barat (NTB), Banten, Kepulauan Riau, Sulawesi Tengah, Sulawesi Barat dan Sulawesi Tenggara.

Produksi rumput laut setiap tahun terus mengalami peningkatan, dari sebesar 2,574 juta ton pada tahun 2009 menjadi 3,082 juta ton pada tahun 2010. Produksi tahun 2010 melewati target yang telah ditetapkan KKP sebesar 2,574 juta ton. Peningkatan produksi tersebut ditempuh dengan ekstensifikasi (memperluas unit usaha budidaya) dan intensifikasi atau peningkatan jumlah produksi melalui penambahan jumlah setiap unit usaha budidaya untuk pengembangan rumput laut.

Hikmayani (2006) mengungkapkan potensi pasar rumput laut Indonesia sangat besar, akan tetapi di beberapa daerah mutu rumput laut yang dihasilkan tidak sesuai dengan kriteria industri. Hal senada juga diungkapkan oleh Ismail (2009), usaha budidaya rumput laut menghadapi berbagai masalah mulai dari pemilihan lahan/lokasi (metode budidaya yang digunakan tidak sesuai dengan lokasi yang dipilih), bibit (sebagai besar petani masih menggunakan bibit yang bersumber dari hasil pengembangan vegetative), hama dan penyakit, kelembagaan, pemasaran, dan pengolahan (dalam hal ini petani tidak melakukan proses penjemuran sehingga kadar air rumput laut masih tinggi (40 persen). Proses pengolahan yang tidak sempurna ini menyebabkan rumput laut rusak pada waktu penyimpanan dan pengangkutan rakibta harga jual rumput laut menjadi lebih rendah.

Irianto (2006) menambahkan permasalahan rumput laut Indonesia adalah keterbatasan akses petani rumput laut terhadap pasar dan informasi pasar. Hal ini disebabkan karena hubungan antara lembaga pemasaran tidak fair sehingga mengurangi efisiensi ekonomi aktivi- tas budidaya rumput laut. Irianto (2006) tidak menjelaskan berapa tingkat efisiensi ekonomi dan dampak kebijakan pemerintah terhadap aktivitas budidaya rumput tersebut. Kegagalan pasar sering disebabkan oleh adanya campur tangan pemerintah sehingga pasar menjadi tidak efisien.

Akibat berbagai permasalahan itu, komoditas rumput laut tidak dapat dimanfaatkan secara optimal dari sisi ekonomi, sehingga Indonesia bisa dihadapkan impor rumput laut dalam jumlah dan nilai yang relatif besar. Hal ini juga mengindikasikan ada faktor-faktor ekonomi dan non-ekonomi yang tidak berfungsi dengan benar seperti saluran pemasaran yang panjang, bibit rumput laut yang jelek, dan faktor teknis lainnya. Sangat dibutuhkan peningkatan efisiensi ekonomi, pemanfaatan teknologi pada saat pembibitan, pembesaran, pengolahan, dan pemasaran yang pada akhirnya usaha aquaculture ini bisa ditingkatkan kontribusinya pada pembangunan ekonomi daerah dan penciptaan lapangan kerja.

Usaha aquaculture ini merupakan salah satu komoditi ekspor yang sangat potensial untuk dikembangkan karena bisa dilakukan tanpa membutuhkan modal yang besar sehingga bisa diandalkan untuk pengembangan skala kecil dan menengah (UMKM). Selain itu, dari segi pasar, komoditas aquaculture ini memiliki pasar yang sangat luas karena bisa berupa produk derivatif dalam bentuk food grade dan non food grade. Ditambah lagi, permintaan dunia terhadap produk ini sangat tinggi, sebagai bahan baku komestik, obat-obatan, dan bahan baku makanan. Di sisi lain, rumput laut bisa dibudidayakan dengan teknologi sederhana, sehingga hal ini bisa menjadi alternatif mata pencaharian bagi masyarakat pesisir yang dari tahun ke tahun mengeluh pada penurunan hasil tangkapan. Hal tersebutlah yang menjadikan rumput laut dipilih sebagai produk yang masuk dalam program revitalisasi perikanan. Bagaimana insentif ekonomi terhadap pengembangan usaha budidaya rumput laut, itulah yang menjadi tujuan dari penelitian ini. 


\section{METODE PENELITIAN}

\section{Teknik Analisis Data}

Penelitian sebelumnya yang memakai metodologi ini adalah penelitian pada sektor pertanian di Spanyol yang dilakukan oleh Martinez, Tadeo, Estruch, pada tahun 2008. Spanyol merupakan salah satu negara Eropa penghasil komoditas pertanian sangat penting di Eropa, salah satunya adalah pada komoditas padi. Hal yang sama juga dilakukan oleh Gomez-Limon, Riesgo, Arraiza, pada tahun sebelumnya (2004). Sedangkan di Asia sendiri, metodologi sudah dilakukan oleh Mohanty, Fang, dan Chaudhary, pada tahun 2003.

Menurut Soetriono (2009), pengembangan usaha suatu komoditas, didukung oleh faktor internal seperti usaha itu sendiri (bibit, tenaga kerja, modal, risiko, pesaing, teknologi, pupuk, dan obat-obatan), permintaan konsumen dan pengembangan agroindustri untuk menciptakan nilai tambah dari suatu komoditas, lingkungan, transportasi, sarana dan prasarana, dan jenis pasar yang dihadapi. Dari sisi eksternal ada lima faktor yang berpengaruh seperti pertama) kebijakan internasional yang berupa pasar luar negeri, kondisi perekonomian dunia, kesepakatan internasional, dan politik perdagangan antarnegara pemasok, kedua) kondisi sosial ekonomi masyarakat yang menekuni usaha budidaya, ketiga) peluang pasar domestik dan luar negeri, keempat) kebijakan domestik seperti keberpihakan kebijakan pemerintah terhadap pengembangan usaha suatu komoditas, kelima) kondisi perekonomian dalam negeri (Hussain, Anwar, Hussain, 2006)

Menurut Pearson, gotsch, et al (2003) analisis ini menggunakan sebuah model analisis yang berfungsi sebagai alat informasi mengenai keberpihakan pemerintahan terhadap sektor pertanian/perikanan/sumberdaya alam dan informasi tentang ketidaksempurnaan pasar dari faktor domestik. Menurut Budidarsono dan Wijaya (2003), model ini disusun dengan membuat sebuah perbandingan antara neraca sistem usaha tani/perikanan atau penggunaan lahan yang dihitung dengan harga finansial pada pasar lokal dan neraca lainnya yang dihitung dengan estimasi harga ekonomisnya yang mencerminkan efisiensi penggunaan sumberdaya. Untuk menganalisis seberapa besar tingkat perbedaan harga/keuntungan sebagai dampak dari adanya kebijakan pemerintah atau ketidaksempurnaan pasar maka harus dihitung selisih antara hasil perhitungan dengan menggunakan harga finansial dan hasil perhitungan dengan menggunakan harga ekonomisnya. Selisih dari hasil perhitungan antara harga finansial dan harga ekonomis ini disebut dengan istilah effect of divergence.

Setiap selisih yang muncul dari perbedaan kedua harga tersebut menjadi sinyal dari adanya efek dari sebuah keberpihakan atau efek kebijakan atau kegagalan pasar dalam suatu sistem ekonomi. Sangat menguntungkan bagi masyarakat yang merasakan suatu sistem yang bisa membuat harga efisien dalam ekonomi pasar, karena terjadi efisiensi produksi dan efisiensi alokasi sumberdaya. Pada kenyataannya, sistem harga belum tentu pasti akan memberikan keuntungan pada pelaku, karena itu dibutuhkan campur tangan pemerintah sehingga terjadi kegagalan pasar.

Perhitungan dimulai dengan mengidentifikasi biaya-biaya yang timbul selama proses budidaya, penjemuran, dan transportasi dan uang yang diterima dari suatu aktivitas produksi. Ada empat tahapan yang dilakukan, pertama penentuan input dan output fisik. Biaya untuk input-input produksi tersebut meliputi biaya pembelian bibit, upah panen, upah pemeliharaan, upah ikat, penyusutan peralatan, dan biaya lainnya (Aysa, 2005). Sedangkan output fisik yang dihasilkan adalah rumput laut kering sebagai bahan baku untuk industri makanan, obat-obatan, dan kosmetik.

Kedua, adalah tahap penentuan harga bayangan, pada input harga bayangan ditentukan dengan menggunakan faktor konversi. Pada ouput harga bayangan ditentukan dengan membuat rataan harga ekspor saat di pelabuhan yang sebelumnya dikonversi dalam nilai tukar US\$ bayangan (Suprapto, 2005). Ketiga, adalah pengalokasian biaya tataniaga yang meliputi biaya pengangkutan dari pembudidayaeksportir-bandara ekspor dan biaya penanganan. Keempat, pemisahan semua biaya dalam 
faktor asing dan domestik. Faktor domestik merupakan barang-barang domestik yang tidak diperdagangkan di pasar internasional, sebaliknya faktor asing adalah barang-barang yang diperdagangkan di pasar internasional.

Setelah itu menghitung profitabilitas yaitu merupakan kemampuan dari suatu usaha aquaculture menciptakan keuntungan dari pemanfaatan sumberdaya. Seperti harga, profitabilitas terdiri dari dua jenis yaitu profitabilitas finansial dan profitabilitas ekonomis. Profitabilitas finansial merupakan ukuran dari daya saing dari sebuah sistem usaha budidaya pada tingkat teknologi dan kebijakan tertentu baik berupa insentif ekonomi (Master dan Nelson, 1995). Profitabilitas ini mengacu pada penerimaan dan pengeluaran aktual, sebaliknya profitabilitas ekonomis mengacu pada penerimaan dan pengeluaran pada harga bayangan (nilai pengorbanan atas penggunaan sumberdaya tersebut).

Profitabilitas ekonomis merupakan gambaran tingkat efisiensi dari suatu sistem usaha budidaya atau penggunaan lahan. Harga mengacu pada harga-harga internasional, yaitu harga c.i.f untuk barang dan jasa yang diimpor, dan harga f.o.b untuk barang dan jasa yang diekspor (Yao, 1997). Harga-harga tersebut harus terbebas dari berbagai insentif ekonomi pemerintah dalam perdagangan, seperti pajak, subsidi, dan tarif. Tujuan dari membebaskan harga dari insentif ekonomi tersebut adalah karena dalam analisis ini melihat seberapa besar pengaruhnya insentif ekonomi yang diberikan oleh pemerintah dalam pembentukan keuntungan, penerimaan, dan biaya. Seberapa besar penerimaan atau keuntungan yang diterima oleh pembudidaya tanpa atau dengan insentif ekonomi pemerintah seperti pajak, subsidi, dan tarif.

Secara harfiah ekonomis, insentif merupakan sebuah dorongan atau rangsangan yang diberikan oleh pengambil keputusan atau pemerintah kepada sebuah usaha supaya pelaku yang menggeluti usaha tersebut bekerja lebih keras lagi (Samosir dan Wibowo, 2004). Pemerintah sudah selayaknya memberikan perlakuan secara khusus kepada usaha budidaya rumput laut, karena mampu menyerap tenaga kerja di daerah dan bisa dilakukan siapa saja, karena tidak membutuhkan modal yang besar dan teknologi yang tinggi. Insentif ekonomi ini diharapkan mampu menyejahterakan dan menjadi alternatif mata pencaharian bagi masyarakat pesisir yang mengalami penurunan hasil tangkapan dari tahun ke tahun.

Pemberian insentif ekonomi dapat dilakukan dengan membuat kebun pembibitan, karena selama ini yang menjadi salah satu keluhan pembudidaya adalah bibit yang tidak bermutu dan sulitnya memperolehnya. Insentif ekonomi itu tidak hanya terbatas pada pemberian subsidi, keringanan pajak, juga pembentukan kelompok kerja yang melibatkan instansi-instansi terkait untuk menangani masalah pengembangan usaha budidaya rumput laut. Selain itu, pemerintah juga dapat memberikan keringanan pajak bagi industri pengolahan rumput laut yang menampung bahan baku dari usaha budidaya. Insentif ekonomi diberikan juga ditujukan untuk mengurangi kesenjangan wilayah selama ini. Pemerintah diharapkan mampu menyediakan sarana dan prasarana untuk pengembangan usaha budidaya rumput laut.

Sebagai contoh dampak dari insentif yang diberikan oleh pemerintah adalah subsidi. Sebagai salah satu dampak pemberian subsidi terhadap barang substitusi impor dan barang yang berorientasi untuk promosi ekspor, seperti rumput laut yang dapat diekspor ke Eropa, Jepang, dan Amerika, adalah harga yang diterima produsen lebih tinggi dari harga di pasaran dunia. Hal ini menyebabkan produksi rumput laut meningkat di dalam negeri, sedangkan harga yang diterima konsumen tetap sama dengan harga di pasaran dunia. Dampak dari subsidi adalah mengatasi negara dalam impor, karena subsidi menyebabkan jumlah barang yang diimpor menurun.

Subsidi menyebabkan barang yang tadinya diimpor dapat diproduksi sendiri dengan biaya yang dikorbankan sebesar subsidi yang diberikan pemerintah. Hal ini membuktikan subsidi sangat berguna sekali pada konsumen dan produsen untuk output yang berpotensi diimpor. Indonesia harus mengurangi ketergantungan terhadap barang impor untuk kemandirian pangan masyarakat dan negara. Saat ini banyak 
sekali barang yang diimpor oleh pemerintah, seperti garam, kentang, bawang, dan buah. Untuk sektor perikanan, pemerintah sudah memberikan subsidi secara riil, yaitu subsidi bahan bakar minyak untuk para nelayan, namun subsidi riil terhadap pengembangan usaha aquaculture masih sedikit sekali, khususnya untuk pengembangan usaha budidaya rumput laut. Adapun rumus matematika yang digunakan dalam model analisis adalah:

\section{Keuntungan finansial $=$}

Penerimaan Finansial - (Biaya pada nilai finansial)

\section{Keuntungan ekonomis $=$}

Penerimaan ekonomis - (Biaya pada nilai ekonomis)

\section{Kebijakan input $=$}

Nilai finansial

Nilai ekonomi

\section{Kebijakan output $=$}

Penerimaan finansial

Penerimaan Ekonomi

\section{Nilai dari Proteksi $=$}

(Penerimaan pada harga finansial - Biaya input pada harga finansial)

(Penerimaan pada harga ekonomis Biaya input pada harga ekonomis)

\section{Nilai dari Subsidi $=$}

Pendapatan karena distorsi pasar

Penerimaan pada harga ekonomis

7. Harga ekonomis diperoleh dari $=$ Harga $R L$ dalam dolar US\$ $x$ (Konversi nilai dolar dalam Rupiah/Harga bayangan nilai tukar rupiah) - transportasi ke pelabuhan

\section{Sumber Data dan Cara Pengumpulan Data}

Data dikumpulkan dengan melakukan wawancara terhadap petani rumput laut, pengambil kebijakan, perusahaan, pemasar, dan instansi terkait. Pertanyaan yang diajukan kepada pembudidaya rumput laut adalah aspek teknis usa- ha budidaya rumput laut, aspek finansial, dan aspek kelembagaan. Pengambil kebijakan yang diwawancarai adalah dari Dinas Perikanan dan Kelautan, Penyuluh, dan Bappeda. Pihak Perusahaan dan Pemasar yang diwawancarai adalah BDS. Selain itu juga diwawancarai pedagang rumput laut sebanyak tiga orang dari lima pedagang yang ada. Penelitian dilakukan di Bone, sebagai salah satu sentra pada usaha budidaya rumput laut, yang tadinya merupakan usaha tambak udang yang dialihkan karena kerugian yang diderita petani oleh penyakit udang.

\section{HASIL DAN PEMBAHASAN}

\section{Aspek Ekonomis}

Dilihat dari aspek ekonomis, mengindikasikan usaha ini mampu mendatangkan tambahan pendapatan negara sebesar US \$0,03, karena nilai komponen dari input tidak impornya adalah $<1(0,03)$. Dalam kata lain, pengembangan usaha ini memiliki daya saing yang bersifat dinamis, dimana negara yang memiliki daya saing ini harus dapat mempertahankannya, karena negara lain dapat menyainginya atau tergantikan oleh komoditas substitusinya. Keunggulan dari daya saing ini adalah suatu negara akan mengekspor komoditi yang banyak memanfaatkan faktor produksi yang berlimpah di negaranya, tetapi mengimpor komoditi yang banyak membutuhkan faktor produksi yang langka di negaranya. Untuk setiap 1 US \$ pendapatan dari ekspor yang dihasilkan dari kegiatan rumput laut, hanya membutuhkan biaya tidak impornya sekitar US $\$ 0,03$.

Tidak salah bila komoditas rumput laut termasuk komoditas yang direvitaslisasi oleh pemerintah. Dalam usaha budidaya ini, sedikit sekali bahan input yang diimpor. Mulai dari tenaga kerja, bibit, sampai pada peralatan dan perlengkapan. Karena itu pada perhitungan komposisi input impor dan input produksi dalam negeri, terlihat nilai input produksi dalam negeri lebih besar ketimbang input impor. Hal ini akan menambah pendapatan negara dari sisi ekspor karena karena komposisi input impor lebih kecil dari input produksi dalam 
negeri. Ironisnya, Indonesia baru sebatas mengekspor bahan baku, yang berarti nilai tambah suatu produk sangat kecil sekali. Nilai tambah suatu produk tidak hanya memberikan keuntungan pada produsennya saja, tapi juga menciptakan lapangan kerja yang sangat penting untuk mengatasi pengangguran pada masyarakat pesisir (Tabel 1).

Pada tingkat harga privat, komoditi ini juga mempunyai daya saing, karena nilai dalam penggunaan biaya pada harga privatnya yang < $1(0,04)$. Pada saat ini rumput laut merupakan komoditas unggulan di sektor kelautan dan perikanan, selain tuna dan udang. Modal yang dibutuhkan untuk usaha ini laut tidak terlalu besar, sedangkan pemeliharaannya dapat dilakukan dengan mudah. Rumput laut dipanen pada umur 45 hari, karena modal dan biaya yang dibutuhkan kecil maka tingkat keuntungan rumput laut di atas rata-rata.

Keuntungan ekonomis pada usaha ini $>0$ (Rp98.379.225,9), artinya tanpa stimulus ekonomis dari pemerintah, sistem komoditi budidaya ini sudah efisien dalam penggunaan sumberdaya sehingga mampu memberikan keuntungan bagi pengelola sumberdaya ini. Hal ini membawa implikasi komoditi rumput laut menjadi prioritas dalam setiap kebijakan pemerintah, sehingga menempatkan komoditas ini menjadi salah satu produk yang masuk dalam program revitalisasi pemerintah. Tingkat keuntungan ekonomis budidaya rumput laut lebih besar karena potensi lahan rumput laut di Bone sangat besar (93.929 Ha dengan realisasi lahan seluas $50,5 \mathrm{Ha}$ ).

Membudidayakan komoditas ini bagi masyarakat pesisir ada sebagai penghasilan utama, ada juga sebagai penghasilan sambilan selain sebagai nelayan dan petani sawah. Rumput laut telah nyata memberikan kehidupan yang lebih layak kepada petani, dan mampu memberikan pendapatan yang kontinyu dan dapat diandalkan. Selain membudidayakan rumput laut di lahan sendiri, ada juga petani yang menggarap lahan orang lain. Petani penggarap ini mendapatkan imbalan $1 / 3$ dari rumput laut yang diproduksi (bersih), sedangkan pemilik lahan mendapatkan $2 / 3$ bagian. Selain menyediakan lahan pemilik juga menyediakan bibit, pupuk, dan sarana produksi lainnya. Pemilik lahan mengontrak petani penggarap dalam kurun waktu tertentu. Bila terjadi kegagalan produksi maka risiko ditanggung berdua, dalam hal ini penggarap rugi tenaga dan waktu sedangkan pemilik lahan rugi modal dan sarana produksi.

Insentif ekonomi yang diberikan pemerintah berupa kebijakan, keringanan pajak, atau subsidi, belum menyentuh secara efektif usaha aquaculture ini. Hal itu bisa dilihat dari nilai dari keefektifan proteksi terhadap suatu komoditas yang kurang < $1(0,67)$. Dalam hal ini, pemerintah sudah membuat kebijakan untuk mengembangkan usaha aquaculture ini. Melalui Dinas Kelautan dan Perikanan bekerjasama dengan pihak BPPT sudah mengembangkan peralatan yang berguna untuk menguji tingkat kekeringan rumput laut, tapi pembudidaya rumput laut belum memanfaatkan peralatan ini dalam menguji mutu rumput laut yang dihasilkan. Hal ini disebabkan karena kurangnya tingkat kesadaran pembudidaya menggunakan alat tersebut sebagai alat bantu untuk mengetahui tingkat kekeringan rumput laut yang dihasilkan.

Selain itu, menurut pembudidaya alat tersebut tidak sederhana untuk digunakan, karena teknologi yang diciptakan tidak melihat latar belakang konsumen yang rendah. Alhasil, pem-

Tabel 1. Nilai Hasil Aspek Ekonomi

\begin{tabular}{lc}
\multicolumn{1}{c}{ Keterangan } & Nilai \\
\hline Komponen dari input impor & 0,04 \\
Komponen dari input tidak impor & 0,03 \\
Keefektifan kebijakan insentif terhadap suatu komoditas & 0,67 \\
Nilai subsidi untuk pembudidaya & $-0,33$ \\
Keuntungan Finansial & $64.890 .964,5$ \\
Keuntungan Ekonomis & $98.379 .225,9$ \\
\hline
\end{tabular}

Sumber/Source: Data Diolah/Data Procesed, 2011 
Tabel 2. Identifikasi Permasalahan Aspek Ekonomis Pengelolaan Rumput Laut di Bone

\begin{tabular}{|c|c|c|}
\hline Aspek & Permasalahan & Pemecahan Masalah \\
\hline $\begin{array}{l}\text { Aspek } \\
\text { Ekonomis }\end{array}$ & $\begin{array}{l}\text { - belum ada standarisasi harga rumput laut } \\
\text { diantara beberapa daerah penghasil rumput } \\
\text { laut } \\
\text { - } \text { pada proses pembelian rumput laut masih } \\
\text { ada pedagang pengumpul yang tidak } \\
\text { menggolongkan berdasarkan kualitas atau } \\
\text { grade } \\
\text { - informasi harga di tingkat industri tidak } \\
\text { sampai ke petani dan harga berubah sewaktu- } \\
\text { waktu } \\
\text { - Meski usaha ini sudah sangat menguntung- } \\
\text { kan secara ekonomis tapi kurang mendapat- } \\
\text { kan mendukung kebijakan dari pemerintah } \\
\text { ini terlihat dari analisis insentif ekonomi }\end{array}$ & $\begin{array}{l}\text { - Penentuan harga disesuaikan dengan } \\
\text { grade/kualitas rumput laut } \\
\text { - Harus sudah dimulai sosialisasi tentang } \\
\text { berbagai kualitas rumput laut beserta } \\
\text { harganya } \\
\text { - Informasi harga harus transparan dari } \\
\text { pedagang ke petani, harus dibuat kesepa- } \\
\text { katan harga untuk setiap pembelian. } \\
\text { - Dukungan dari pemerintah tersebut } \\
\text { bukan hanya dalam bentuk subsidi bisa } \\
\text { dalam pembinaan mutu rumput laut } \\
\text { yang selama ini sudah dilakukan pihak } \\
\text { BDS atau bantuan dalam kemudahan } \\
\text { mendapatkan bibit yang berkualitas }\end{array}$ \\
\hline
\end{tabular}

budidaya rumput laut selama ini hanya menggunakan "feeling" dalam menentukan tingkat kekeringan yang dihasilkan, tentu saja tingkat keakuratannya kurang tepat ketimbang menggunakan alat bantu ini. Biasanya masyarakat melakukan pengeringan selama seminggu. Sebaliknya menurut Dinas Kelautan Perikanan Bone, kurangnya tingkat kesadaran masyarakat memanfaatkan peralatan tersebut karena tanpa menggunakan alat tersebut saja rumput laut mereka terjual dengan harga tinggi, selain itu sosialisasi mengenai alat bantu tersebut masih kurang.

Pemerintah belum memberikan subsidi langsung ke pembudidaya, tidak seperti usaha penangkapan yang mendapatkan subsidi langsung berupa harga BBM (bahan bakar minyak) yang relatif murah untuk nelayan. Hal ini bisa dilihat dari nilai subsidi untuk pembudidaya yang bertanda negatif $(-0,3)$. Rencananya Dinas Kelautan dan Perikanan akan membuat kebun bibit rumput laut sebagai bentuk subsidi pemerintah ke pembudidaya. Rencana program tersebut dibuat setelah mendengar banyaknya keluhan yang banyak dikemukakan oleh petani saat ini yaitu masalah bibit yang harus mereka dapatkan dari daerah lain. Pembudidaya rumput laut di Bone mendapatkan bibit rumput laut dari Palopo dan Bantaeng. Awalnya bibit rumput laut didatangkan dari daerah lain seperti Palopo dan Bantaeng, tapi untuk masa produksi berikutnya penyediaan rumput laut untuk bibit digunakan dengan menyisakan rumput laut hasil panen.

Pemasaran rumput laut secara umum masih terkendala pada beberapa hal yaitu (a) belum ada standardisasi harga rumput laut (b) masih ada pedagang pengumpul yang pada proses pembelian rumput laut tidak digolongkan berdasarkan kualitas atau grade, (c) informasi harga rumput laut sangat kurang bagi petani. Pada lokasi survei sampai saat ini belum ada standardisasi harga rumput laut baik yang berbentuk basah maupun kering. Hal ini disebabkan oleh perbedaan jarak antara lokasi produksi dan lokasi pemasaran. Perkembangan informasi harga rumput laut merupakan salah satu permasalahan yang menghambat pemasaran rumput laut. Minimalnya informasi tersebut disebabkan oleh adanya persaingan antarpedagang atau agen-agen perusahaan di lokasi budidaya. Persaingan ini menyebabkan tertutupnya informasi harga dari pedagang kepada petani.

\section{Aspek Teknis}

Aspek teknis yang dilakukan adalah analisis teknis pendapatan usaha, analisis imbangan penerimaan biaya, analisis payback period, dan analisis pulang pokok. Perhitungan analisis usaha menunjukkan bahwa usaha budidaya rumput laut ini sangat menguntungkan. Para pemodal mengalami keuntungan finansial sebesar Rp29,772,000 per tahunnya. Sehingga investasi yang ditanamkan dapat kembali selama 
Tabel 4. Investasi Budidaya Rumput Laut di Bone

\begin{tabular}{lr}
\hline Investasi & Nilai \\
\hline Perahu & $1,000,000$ \\
Waring & $1,500,000$ \\
Mesin pompa & $3,500,000$ \\
Saplak & 8,000 \\
Total Investasi & $6,008,000$ \\
\hline
\end{tabular}

Sumber: Wawancara

barang-barang investasi tersebut pada umur ekonomisnya. Ini bisa dilihat dari nilai Payback Period (PP) yang nilainya 0,2 atau investasi sudah kembali pada tahun pertama.

Investasi kembali terhitung sangat cepat karena kurang dari setahun, hal ini disebabkan karena keuntungan yang diperoleh dalam budidaya rumput laut cukup besar, akan tetapi investasi yang dikeluarkan relatif kecil yaitu hanya sebesar Rp6.000.000. Sedangkan nilai $\mathrm{R} / \mathrm{C}$ mengindikasikan sebesar 2,1 yang artinya setiap rupiah biaya yang dikeluarkan pengolah maka diperoleh penerimaan sebesar Rp2,1. Nilai BEP (break event point) yang sebesar 13.496.415 mengindikasikan usaha ini akan mencapai titik impas jika dapat menghasilkan penerimaan sebesar Rp13.496.415.

Dalam setahun delapan kali panen dengan bibit sebanyak 2 ton dalam satu hektar. Dalam satu hektar juga menghasilkan 2 ton rumput laut, tapi dalam bentuk rumput laut kering. Adapun investasi yang dibutuhkan dalam budidaya rumput laut di Bone adalah: Perahu sebanyak satu unit, waring, mesin pompa, dan saplak. Nilai investasi yang terbesar adalah mesin pompa seharga Rp3,5 juta, sedangkan investasi yang paling murah adalah saplak (Rp8.000). Adapun nilai dari masing-masing investasi budidaya rumput laut di Bone seperti tertera pada Tabel 4.

Sedangkan pengeluaran terbagi dari biaya variabel dan biaya tetap. Biaya variabel meliputi: bibit rumput laut dan pupuk yang banyaknya $10 \mathrm{~kg} / \mathrm{ha}$. Pemupukan dilakukan sebelum dan sesudah panen, dimana terdiri dari pupuk Urea, ZA, dan NPK.Upah tenaga kerja meliputi: tebar benih, pemupukan, pemeliharaan, dan pengeringan tambak. Semua biaya tertera pada Tabel 5 .

Penanganan pascapanen yang salah juga merupakan sebuah masalah dalam pengelolaan budidaya rumput laut. Masih ditemukan petani yang mengeringkan rumput laut di atas tanah yang bercampur batu-batu kecil, akibatnya kotoran dan batu-batuan terangkut dalam pengemasan. Namun hal ini sudah jarang ditemukan, pada umumnya tingkat kesadaran petani rumput laut dalam hal menjaga mutu cukup tinggi, misalnya mengeringkan rumput laut dengan alas. Perlakuan pascapanen yang dilakukan petani di Bantaeng hampir sama dengan lokasi lainnya. Rumput laut yang sudah dipanen kemudian dijemur sampai kekeringan 35 persen dan siap untuk dijual.

\section{Aspek Kelembagaan}

Usaha budidaya ini mulai berkembang tahun 1992 yang dipasarkan ke PT Bantimurung

Tabel 5. Biaya pada Budidaya Rumput Laut di Bone

\begin{tabular}{lr}
\hline Biaya & Nilai \\
\hline Upah tebar benih & 160,000 \\
Upah pemupukan & 240,000 \\
Upah pemeliharaan & $4,800,000$ \\
Upah pengeringan tambak & 160,000 \\
Sewa tambak & 3500000 \\
Bibit Rumput Laut Rp & $22,800,000$ \\
Pupuk & 560,000 \\
\hline
\end{tabular}

Sumber: Wawancara 
Indah. Tapi setelah rumput laut berkembang terjadi penurunan harga yang sangat signifikan sampai pada harga Rp500/kg (rumput laut kering). Sekarang harga Gracillaria $S p$ dan $\mathrm{Eu}$ cheuma mengalami peningkatan 10-15 kali lipatnya. Masyarakat yang membudidayakan rumput laut mendapat bantuan modal dan bibit dari PT BDS (Business Development Centre), dengan syarat masyarakat harus menjual rumput laut ke BDS. Selain itu perusahaan ini juga memberikan bimbingan bagaimana melakukan budidaya rumput laut dan pascapanen yang baik. Seperti rumput laut harus dipanen pada umur 45 hari dan dijemur sampai kering dengan menggunakan waring.

Keterlibatan PT Bantimurung Indah dan PT BDS mengindikasikan besarnya dominasi peran swasta dalam kebijakan usaha rumput laut. Selain itu juga menunjukan kecilnya peran pemerintah dalam mengembangkan usaha pemerintah. Kecilnya peran pemerintah dalam pengembangan usaha rumput laut dapat dilihat dari analisis sebelumnya (analisis ekonomi) dimana kecilnya insentif ekonomi yang diberikan oleh pemerintah untuk mengembangkan usaha ini. Insentif ekonomi itu tidak hanya terbatas pada pemberian subsidi atau keringanan pajak saja, akan tetapi pemerintah dapat memberikan bimbingan teknis tentang usaha aquaculture ini. Dalam kasus ini, malah yang memberikan bimbingan teknis adalah dari pi- hak swasta PT BDS. Padahal mendapatkan bimbingan teknis dan bantuan bibit dari PT BDS, berarti petani harus siap menerima konsekuensi keharusan menjual panen ke perusahaan ini.

Sistem kerja sama antara PT BDS dengan petani sama bentuknya sistem ijon atau tengkulak pada petani padi atau nelayan, dimana petani/nelayan bisa memperoleh modal dan bantuan teknis lainnya, dengan kewajiban menjual ke tengkulak yang telah memberikan bantuan tersebut. Diharapkan peran pemerintah dan insentif ekonomi yang diberikan oleh pemerintah dapat ditingkatkan supaya pembudidaya rumput laut tidak harus menjual ke PT BDS. Selain itu, diharapkan peran pemerintah dalam memutus sistem ketergantungan petani ke PT BDS, hal ini sama saja meminimalisir berkembangannya sistem ijon atau tengkulak dalam industri aquaculture ini.

Ada petugas yang memantau perkembangan budidaya rumput laut anggota BDS. Petugas ini biasanya mengawasi anggota BDS dalam aktivitas budidaya rumput laut yang dikembangkan, mulai dari awal budidaya sampai pada rumput laut dikeringkan. Tapi ada juga pembudidaya rumput laut yang bukan anggota BDS. Bedanya pembudidaya ini tidak mendapatkan bantuan modal dan bibit dari BDS dan tidak ada keharusan untuk menjual rumput laut ke BDS. Menurut wawancara dengan pihak BDS, ada keistimewaan yang diperoleh anggota

Tabel 6. Identifikasi Permasalahan Aspek Teknis Pengelolaan Rumput Laut di Bone

\begin{tabular}{|c|c|c|c|}
\hline No & Aspek & Permasalahan & Pemecahan Masalah \\
\hline & Aspek Teknis & $\begin{array}{l}\text { - Pedagang pengumpul sering menge- } \\
\text { luh mengenai kadar air }\end{array}$ & $\begin{array}{l}\text { - Peningkatan kedasaran petani untuk } \\
\text { menjemur rumput laut secara benar }\end{array}$ \\
\hline & & $\begin{array}{l}\text { - Masih ada petani yang menjemur } \\
\text { tanpa alas }\end{array}$ & $\begin{array}{l}\text { - Peningkatan kedasaran petani untuk } \\
\text { menjemur rumput laut secara benar }\end{array}$ \\
\hline & & $\begin{array}{l}\text { - Kurangnya penyuluhan dan pembi- } \\
\text { naan dari instansi terkait sehingga } \\
\text { buruknya penanganan pasca panen } \\
\text { dibeberapa lokasi }\end{array}$ & $\begin{array}{l}\text { - Instansi yang terkait melakukan pem- } \\
\text { binaan kepada petani terutama masa- } \\
\text { lah mutu. }\end{array}$ \\
\hline & & $\begin{array}{l}\text { - Serangan penyakit ice-ice musim } \\
\text { kemarau }\end{array}$ & $\begin{array}{l}\text { - Petani diharapkan jangan memperce- } \\
\text { pat masa panen ketika diserang pe- } \\
\text { nyakit ice-ice karena hal ini mempe- } \\
\text { ngaruhi image mutu rumput laut yang } \\
\text { dihasilkan pada masa yang akan da- } \\
\text { tang }\end{array}$ \\
\hline
\end{tabular}

Sumber:Wawancara 
Tabel 7. Perbandingan Manfaat antara Menjadi Anggota BDS dengan Bukan Anggota BDS

\begin{tabular}{ll}
\hline Anggota Business Developing Services & Bukan Anggota Business Developing Services \\
\hline Bibit disediakan mitra usaha dalam hal ini BDS & Penyediaan bibit atas inisiatif sendiri \\
Harus menjual kepada mitra usaha dalam hal ini BDS & Memasarkannya ke pedagang pengumpul dan BDS \\
Aktivitas budidaya diawasi pihak BDS & Mutu diawasi sendiri \\
Modal dibantu pihak BDS & Modal sendiri \\
\hline
\end{tabular}

Sumber: Wawancara

BDS dalam hal harga, yaitu pihak BDS memberikan harga lebih tinggi dibanding bukan anggota.

Selain itu pihak BDS lebih mengutamakan membeli rumput laut dari anggota ketimbang bukan anggota. Dengan mutu yang sama harga yang diberikan pihak BDS lebih tinggi (berkisar Rp300-Rp500) ketimbang harga yang diberikan pembeli lain. Meski saat ini, harga yang diberikan oleh pihak BDS lebih tinggi dibanding harga pembeli lainnya, tetap saja ketergantungan petani terhadap PT BDS harus tetap dikurangi, karena ketergantungan yang tinggi dapat memperlemah posisi mereka dalam penentuan harga, yang pada akhirnya membuat keuntungan yang diterima petani semakin lebih kecil.

Hal ini disebabkan karena sistem yang ditawarkan PT BDS hampir sama dengan sistem yang ditawarkan oleh sistem tengkulak. Hanya saja saat ini, harga yang diberikan oleh PT BDS lebih tinggi dibandingkan penjual lain, karena permintaan terhadap rumput laut masih tinggi. Dikuatirkan, ketika permintaan rendah dan ketergantungan petani terhadap PT BDS sangat tinggi, akhirnya bargaining position pembudidaya dalam pembentukan harga sangat rendah, yang pada akhirnya dapat merugikan pihak pembudidaya sendiri.
Petani membudidayakan rumput laut dalam bentuk kelompok petani, tapi dalam hal ini kelompok tani sering dimanfaatkan hanya dalam proses pemberian bantuan atau pinjaman. Fungsi kelompok petani belum optimal, aktivitas pertemuan baru meningkat bila ada bantuan baik dari pemerintah atau pihak lain. Dalam peningkatan mutu, kelompok petani belum optimal, bahkan yang sering membina masyarakat adalah pihak BDS, bukan kelompok petani.

Permasalahan yang sering terjadi adalah bagaimana industri atau pedagang pengumpul memposisikan sebagai partner atau relasi yang mempunyai hubungan yang saling menguntungkan. Selama ini pedagang memposisikan petani hanya sebagai pembeli. Hadirnya pihak BDS yang melaksanakan fungsi pembelian dan pemberi modal, dalam proses penentuan harga tergantung pada pihak BDS, karena ada petani harus menjual ke pihak BDS.

Budidaya rumput laut mulai berkembang tahun 1992, diawali dengan pengambangan di bawah binaan dan sekaligus pembeli rumput laut yaitu PT Bantimurung Indah. Setelah berkembang harga rumput laut jatuh yang disebabkan karena mutu yang dihasilkan tidak memenuhi kriteria industri. Penurunan harga sampai pada tingkat Rp500/kg (rumput laut

Tabel 8. Identifikasi Permasalahan Aspek Kelembagaan

\begin{tabular}{|c|c|c|c|}
\hline No & Aspek & Permasalahan & Pemecahan Masalah \\
\hline 1. & Aspek Kelembagaan & 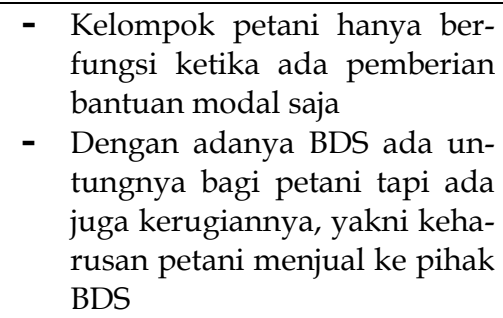 & $\begin{array}{l}\text { - Peningkatan peran kelompok petani mi- } \\
\text { sal sebagai pembina atau sebagai pema- } \\
\text { sar sehingga saluran pemasaran tidak } \\
\text { panjang. } \\
\text { - Bargaining position petani harus kuat } \\
\text { lagi dalam penentuan harga dengan } \\
\text { pihak BDS }\end{array}$ \\
\hline
\end{tabular}


kering). Rumput Laut yang dihasilkan petani banyak yang tidak diterima pedagang besar di Makasar. Ditengarai karena mutu rumput laut yang dihasilkan tidak memenuhi kriteria industri. Masalah mutu ini, tidak hanya kesalahan dari petani semata tapi ada juga andil dari pedagang pengumpul.

Umur panen normal atau ideal bagi rumput laut adalah 45 hari, namun biasanya petani memanen tanaman rumput lautnya pada umur 40 hari, 35 hari bahkan ada juga yang memanen rumput laut padan umur 30 hari. Hal ini juga merupakan faktor yang mempengaruhi kualitas rumput laut. Ada kecenderungan di kalangan petani untuk menjual rumput laut tanpa standar umur (45 hari). Hal ini terlihat dengan adanya pemikiran bahwa berapapun umur tanam dari rumput laut, hasilnya akan dibeli dengan harga yang sama. Pada akhirnya petani tidak berpikir panjang, yang penting sudah mendapatkan untung maka rumput lautnya akan dipanen. Dampak seperti ini berawal dari target produksi yang dikenakan oleh perusahaan kepada pengumpul, atau target ekspor dari industri yang harus dipenuhi setiap bulannya. Sehingga pedagang pengumpul membeli rumput laut tidak sesuai dengan kriteria yang diterima yang ditentukan industri.

\section{SIMPULAN}

Dilihat dari aspek ekonomis, mengindikasikan usaha ini mampu mendatangkan tambahan pendapatan negara sebesar US $\$ 0,03$, karena nilai komponen dari input tidak impornya adalah $<1(0,03)$. Tidak salah bila komoditas rumput laut termasuk komoditas yang direvitalisasi oleh pemerintah. Dalam usaha budidaya ini, sedikit sekali bahan input yang diimpor. Hal ini akan menambah pendapatan negara dari sisi ekspor karena karena komposisi input impor lebih kecil dari input produksi dalam negeri. Insentif ekonomi yang diberikan pemerintah berupa kebijakan, keringanan pajak, atau subsidi, belum menyentuh secara efektif usaha aquaculture ini. Hal itu bisa dilihat dari nilai dari keefektifan proteksi terhadap suatu komoditas yang kurang $<1(0,67)$. Dalam hal ini, pemerintah sudah membuat kebijakan untuk me- ngembangkan usaha aquaculture ini. Melalui Dinas Kelautan dan Perikanan bekerjasama dengan pihak BPPT sudah mengembangkan peralatan yang berguna untuk menguji tingkat kekeringan rumput laut, tapi pembudidaya rumput laut belum memanfaatkan peralatan ini dalam menguji mutu rumput laut yang dihasilkan. Menurut pembudidaya alat tersebut tidak sederhana untuk digunakan, karena teknologi yang diciptakan tidak melihat latar belakang konsumen yang rendah. Pemerintah belum memberikan subsidi langsung ke pembudidaya, tidak seperti usaha penangkapan yang mendapatkan subsidi langsung berupa harga BBM (bahan bakar minyak) yang relatif murah untuk nelayan. Hal ini bisa dilihat dari nilai subsidi untuk pembudidaya yang bertanda negatif $(-0,3)$.

\section{DAFTAR PUSTAKA}

Aysa, K. 2005. Matrik Kebijakan Usaha Udang. Jurnal Penelitian dan Perikanan Indonesia. Pusat Riset Pengolahan Produk dan Sosial Ekonomi Kelautan dan Perikanan.

Budidarsono, S, Wijaya, K. 2003. Praktek Konservasi dalam Budidaya Kopi Robusta dan Keuntungan Petani. World Agroforestry Centre - ICRAF. Bogor.

Gomez-Limon, J.A, Riesgo, L dan Arraiza M. 2004. Multi-criteria Analysis of Input Use in Agriculture. Journal of agricultural economics research, 55, 541-564. doi: 10.1111/j. 1477-9552.2004. tb00114.x.

Hikmayani, Y. 2006. Aspek Teknis, Kelembagaan, dan Ekonomis Budidaya Rumput Laut di Indonesia. Jurnal Sosek Perikanan dan Kelautan. Balai Besar Riset Sosial Ekonomi Kelautan dan Perikanan.

Hussain, M, Anwar, S, Hussain, Z. 2006. Economics of Sugarcane Production in Pakistan: A Price Risk Analysis. International Research Journal of Finance and Economics.4.7077.

Irianto, H. 2006. Teknologi Pasca Panen Rumput Laut. Diseminasi Teknologi dan Temu Bisnis 
Rumput Laut. Pusat Riset Perikanan Budidaya.

Ismail, Z. 2009. Strategi Optimalisasi Pemanfaatan Budidaya Rumput Laut. Laporan. Pusat Penelitian Ekonomi Lembaga Ilmu Pengetahuan Indonesia. Jakarta: Lembaga Ilmu Pengetahuan Indonesia.

Martinez, E, Tadeo, J, Estruch, V. 2008. The Policy Analysis Matrix with Profit-Efficient Data: Evaluating Profitability in Rice Cultivation. Spanish Journal of Agricultural Research. Instituto Nacional de Investigación y Tecnología Agraria y Alimentaria (INIA).

Masters, W. A., and A. Winter-Nelson. 1995. Measuring The Comparative Advantage of Agricultural Activities: Domestic Resource Costs and the Social Cost-Benefit Ratio. Journal Agric. Econ. 77: 243-50.

Mohanty, S, Fang, C, Chaudhary, J. 2003. Assessing the Competitiveness of Indian Cotton Production: A Policy Analysis Matrix Approach. The Journal of Cotton Science 7:6574.
Pearson, Gotsch, et al, 2003. Applications of the Policy Analysis Matrix in Indonesian Agriculture. www.stanford.edu

Samosir, A, Wibowo, T. 2004. Analisis Efektivitas Pemberian Insentif Fiskal di Kawasan Timur Indonesia (KTI) (Studi Kasus: Kapet Parepare. Jurnal Kajian Ekonomi dan Keuangan Volume 8, No.1.

Soetriono. 2001. Studi Kebijakan Terhadap Komoditas Tebu Guna Mendukung Agribisnis. Jurnal Agribisnis, Vol 2,No.2. JUBC. Jember.

Soetriono.2009. Strategi Peningkatan Daya Saing Agribisnis Kopi Robusta dengan Model Daya saing Tree Five. Bogor: Pusat Analisis Sosial Ekonomi dan Kebijakan Pertanian.

Suprapto. 2005. Keunggulan Kompetitif dan Komparatif Ekspor Ikan Hias DKI Jakarta di Pasar Internasional. BULLETIN Penelitian. No.08.

Yao, S. 1997. Comparative advantages and crop diversification: a policy analysis matrix for Thai agriculture. Journal Agric. Econ. 48: 211-222. 